Research article

\title{
Assessment of naturally occurring radiation in lithofacies of oil field in Niger Delta region and its possible health implications
}

\author{
Emmanuel E. Okoro ${ }^{a, n}$, Amarachi G. Okolie ${ }^{a}$, Samuel E. Sanni ${ }^{b}$, Emmanuel S. Joel ${ }^{c}$, \\ Oluranti Agboola ${ }^{b}$, Maxwell Omeje ${ }^{c}$ \\ a Petroleum Engineening Department, Covenant Untversity Ota, Ngeria \\ ${ }^{b}$ Chemicol Enginering Department, Cowenave Universiry Ota, Nigeria \\ "Physics Department, Covenant Eniversity Ota Migeria
}

\section{A R T I C L E I N F O}

\section{Keywards:}

Niger-Delta

Oil-field

Activity-concentration

Radiological risk

Lithofacies

\begin{abstract}
A B S T R A C T
The accumulation and increase in radionuclide activities of NORMs beyond permissible levels, will lead to health hazards and environmental damages if proper measures are not taken to control their occurrence as well as protect the lives of drillers and the environment. Therefore, evaluations and risk assessments of subsurface lithofacies is inevitable in order to protect people and the environment. Lack of existing Federal environmental regulations to address the presence of NORMs in oil and gas exploration activities in Nigeria, gives credence to this study. However, before these regulations can be developed, adequate research knowledge is needed to better understand the occurrence and distribution of Norms in subsurface lithofacies, as well as quantify the hazards posed by these NORMs to the people in the environment. This study then investigates the occurrence of natural radiation in lithofacies of an oil field region in Niger-Delta area using Hyper Germanium (HPGe) detector. Six (6) samples of different subsurface layers of lithofacies were collected during drilling, and analyzed. The results showed that the measured activity concentration of ${ }^{238} \mathrm{U}$ decreased as the depth increased; the activity concentration of ${ }^{252}$ Th ranged between $11.8 \pm 9.29 \mathrm{~Bq} / \mathrm{kg}$ and $23.1 \pm 8.43 \mathrm{~Bq} / \mathrm{kg}$, while the activity concentration of $^{4} \mathrm{~K}$ ranged from $161.8 \mathrm{~Bq} / \mathrm{kg}$ to $245.4 \mathrm{~Bq} / \mathrm{kg}$. The estimated radiological risks such as absorbed dose rates, annual effective dose rates, radium equivalent index, external hazard index and internal hazard index were determined. The mean values for the estimated radiological parameters were $12.32 \mathrm{nGyh}^{-1}, 15.1049 \mathrm{Svy}^{-1}$, $44.7720 \mathrm{Bqkg}^{-1}, 0.1209$ and $0.131 \mathrm{~B}$ respectively. The gamma index estimated for the samples used were within the standard values recommended by Unscear, 2000. Significantly, this study reveals a distinctive decrease in $232 \mathrm{Th}$ activity with depth within the area under consideration. Based on the compared results, the measured radioactive concentrations and estimated radiological risks were below international reference values.
\end{abstract}

\section{Introduction}

Naturally occurring radioactive materials (NORMs) are present in the natural environment, including subsurface rocks, soil and water. Though the emission of NORMs from these subsurface sources are characterized as low and high level radiations, however, these naturally occurring materials may present health hazards over a long period of exposure to humans/the environment. Although, Oil and gas field development projects are often targeted at organic-rich carbonate, shale and sandstone formations which contain NORMs, however, optimized operations to curb fracturing may increase the NORM concentrations during exploration activities (Smith, 1992; Okoro et al., 2019a,b).
Hydrocarbon bearing formations may have high NORM radiation levels, and an example is the Oriskany sandstone in the Eastern United States. The exploration activities in this oil and gas field produce drill-cuttings that contain NORM radionuclides, and most of these wastes end up at landfills, either as hazardous materials or otherwise. Improper disposal, recycling, and reuse have led to circumstances resulting in contamination and unnecessary public exposures (Snavely, 1989; White, 1992; Hamiat et al., 2001).

Excavation data from underground facies play an important role in the characterization of rocks, since it is impossible to determine the nature of the geological formation without knowing the composition of the rock. In addition, drill cuttings are rock samples that truly represent

\footnotetext{
- Corresponding author.

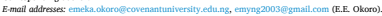

